脂肪肝における血清コリンエステラーゼ活性上昇の意義

\author{
岩村健一郎松崎松平板倉 勝*
}

\begin{abstract}
要 旨 : 脂肪肝高度群 41 例, 俥度群30例, 計71例について, 血清コリンエステラーセ゚と, 肝組織 所見及び臨床検査成績の対比を行った。ChE の上昇は，高度群 $80 \%$ ，軽度群60\%の高率にみと められ，前者の平均值は $5,311 \mathrm{U} / l$ と後者の $4,748 \mathrm{U} / l$ に比し有意に高值を示した。 その上昇度に は, 飲酒習慣, 糖尿病の合併の有無による差はみられなかった。 ChE 上昇に伴い, 高脂血症, 高リポ蛋白血症, 高アルブミン血症が高率にみられた。本症における ${ }^{131} I-R I S A$ 半隇期は8.2日 と軽度短縮を示し，ChE アイソザイムは正常型であった，以上より，ChE 上昇は蛋白異化低下 によるるのではなく，リポ蛋白合成元進に随伴した合成え進によることが示唆された． ChE 上 昇と共にトランスアミナーゼ， $\gamma$-GTP る上昇していたが治療後は, 全て改善低下した. ChE は 脂肪肝の診断に極めて有用であるととるに，その病態の解析にも役立つことを述べた。
\end{abstract}

索引用語： fatty liver cholinesterase

\section{はじめに}

血清 cholinesterase (pseudocholinesterase) (以下 ChE) が, 急性肝炎, 肝硬変などの高度肝障害により活性低下 を来すことは，すでによく知られている事央であり ${ }^{1-6)}$, かつ，その際肝における $\mathrm{ChE}$ 活性む低下している7の であるから，血清活性値の低下は肝細胞機能の障害を反 映するるのと理解される。

他方，筆者はすでに脂肪肝において ChE 活性の上昇 がみられることを発表しだ．その後柴田ら”たよって 同様の成績が報告されているが，その上昇機序に関し てはまたそれはど明らかにされているわけではなく，ま た，本醭素活性の上昇度と肝組織に和ける脂肪化の程度 との関連についての検討成績るみられない。

筆者らは脂肪肝に括ける本醭素の変動を臨床的に解析 し，かつ，肝組織像と対比検討することによって，本症 の病態の一面を考察し, 本醉素測定の診断的意義につい て述べる.

\section{対象および方法}

東海大学病院第 3 内科入入院 $\mathrm{L}$, 腹腔鏡下肝生検に上 り形態学的飞脂肪肝をたは肝の脂肪化を確認した71症例 を対象とした。な HBs 抗原陽性者，急性肝炎経過例

* 東海大学第 3 内科

<受付日54年 8 月 16 日> cholinesterase isozyme hyperlipidemia

および組織学的に慢性肝炎の所見がみられた症例は対 象症例から除外した。また，各症例の病因を考虑して， 2 力月間, それぞれ断酒, 糖尿病治療, 食慨調整, 運動 療法による体重の適正化などをはかった後の検查結果を 治療後の成績とし，治療前の成績と比校検討した. 肝の 組織学的検索は Hematoxylin-Eosin 染色標本により行 い, 光顕上，訮小葉の $50 \%$ 以上の細胞内に脂肪滴がみと められるものを高度群（severe），50\%に達 しないもの を軽度群 (moderate) とした，血液生化学的検查成績 は当院中央検查室に拁ける測定值によったが，ChE は Ellman 法 ${ }^{10)}$, GOT, GPT は UV 法 $\left(37^{\circ} \mathrm{C}\right)$ 湘定值K よった。血清アルブミン量は Bromcrezol green (BCG) 法により測定した。脂肪負荷試験は中性脂肪 $100 \mathrm{~g}$ 含有 試験食を作製し, 早朝空腹時患者江投与, 以後 6 時間絶 食のもとに静脈血を採血し，血中酵素，脂質を測定し た。血中 ${ }^{191}$ I-RISA 半隇期は Sterling 法 ${ }^{11}$ 飞より。 た ChE アイソザイムは Juul 法 ${ }^{12)}$ の改良による Matsuzaki ら ${ }^{13)}$ の方法により，それぞれ測定した。

各群の倹查值は平均值士標準偏差をもって示し, 各群 間の平均值の差は $\mathrm{t}$ 検定により，また治療前後の比較は 階差 $\mathbf{t}$ 検定法により行った。

性, 年齢および関連因子

今回刘象とした症例の男女比は男子60例，女子11例で 
Table 1. Age and sex distributions of patients with severe and moderate fatty liver.

\begin{tabular}{c|rc|rr|r}
\hline \multirow{2}{*}{ Age } & \multicolumn{2}{|c|}{ Severe } & \multicolumn{2}{|c|}{ Moderate } & Total \\
\cline { 2 - 5 } & male & female & male & female & \\
\hline-29 & 7 & 0 & 2 & 0 & 9 \\
$30-39$ & 13 & 1 & 13 & 1 & 28 \\
$40-49$ & 8 & 3 & 10 & 0 & 21 \\
$50-59$ & 5 & 3 & 2 & 1 & 11 \\
$60-$ & 0 & 1 & 0 & 1 & 2 \\
\hline Total & 33 & 8 & 27 & 3 & 71 \\
\hline
\end{tabular}

㐫り，肝の組織検索にもとつく脂肪化高度群のみをみて む，それぞれ33例対 8 例と男子に多くみられた，年路は 30〜 40歳代の青壮年層が約70\%を占めた (Table 1).

空腹時血糖 $120 \mathrm{mg} / \mathrm{d} l$ 以上の糖尿病は高度群 の中に 7 例，軽度群の中に 3 例みられた。本酒換算 1 日 3 合以 上の常習领酒者は各群それぞれ8例および10例であっ た。標準体重 $+20 \%$ 以上の肥満者は31例（全症例 の44 \%)を占めた．糖尿病性变化，常習飲酒，肥満などの要 因を見出せなかった症例は脂肪化高度群に10例，軽度群 に22例あり，また，高度の栄着障害がみられた症例はな W.

\section{ChE 活性}

正常下限界より低値を示した症例はない，正常上限界 を越える高值を示したものは高度群で $80 \%$ ，軽度群で63 \%にみられ，両群間の発生䫇度に有意差をみとめない が，高度群にお和る発性頻度が高い傾向がみられた。活 性値は高度群に和いてて $5,311 \pm 790 \mathrm{U} / l$, 軽度群に打いて 4,748士651であり，前者が後者よりも有意に高值を示し た $(\mathrm{p}<0.01)$. 治療後の活性值はいずれの群に打いても 有意低下し，正常化を示するのも多い，高度群中常 習领酒者に批ける活性値は治療前 $5,388 \pm 998$ ，治療後 $4,594 \pm 1,216$ ，糖尿病性変化を有する者で忙それぞれ $5,264 \pm 866,4,147 \pm 170$ となり, 病因別による特異な差 異はみられなかった。すなおら脂肪肝における $\mathrm{ChE}$ 活 性値の上昇は，病因の如何によらず，肝の脂肪化とのみ 関連することが示唆された (Fig. 1).

\section{血清 GOT,GPT および $\boldsymbol{r}$-GTP}

治療前に GOT が正常上限界 $(40 \mathrm{U} / l)$ を越えて上昇 していたものは，高度群に56\%，軽度群に53\%みられ た. GPT が正常上限界 (40U/l) を越えていたすのは各 群にそれぞれ81\%扰よび83\%にみられ，GOT に乱る

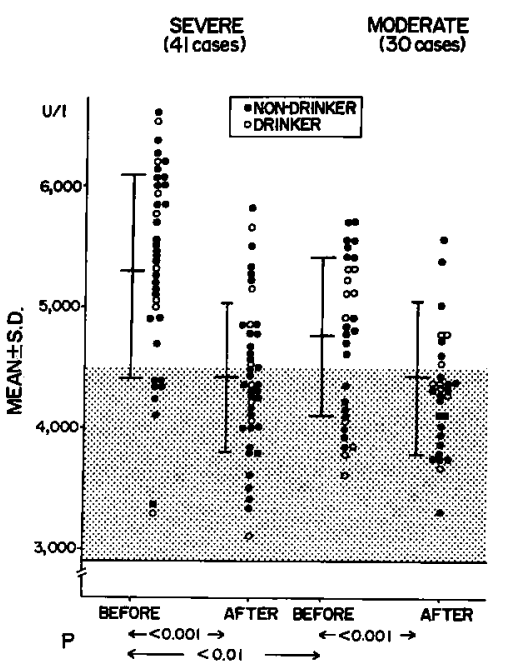

Fig. 1 Serum cholinesterase activity in severe and moderate fatty liver before and after treatment.

GOT

GPT

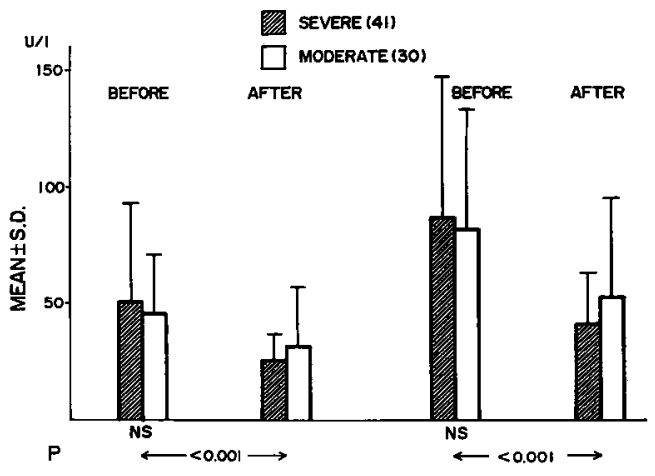

Fig. 2 Serum transaminase levels in severe and moderate fatty liver before and after treatment.

よりも高頻度であった．活性値の上昇をみた症例では全 例 GPT 優位であり，100単位前後を呈するすのが多か った (Fig. 2). しかし，治療後にはGOT, GPT ともに 有意の低下がみとめられた。常習领酒者に批けるGOT 活性值は高度群で $45 \pm 49 \mathrm{U} / l$, 軽度群で $47 \pm 28$, GPT 活

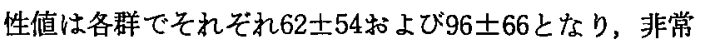

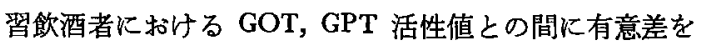
みとめなかった。

$\gamma$-GTP 活性值は高度群 $飞$ 抽いて $95 \pm 158 \mathrm{U} / l$, 軽度群 において $125 \pm 148 \mathrm{U} / l$ と極めて広い活性分布を示した が，非常習领酒者のみについてみると，各群に打いてそ 


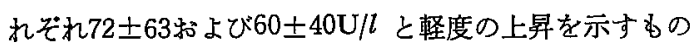
が多かった。また常習领酒者では各群に扎いてそれぞれ

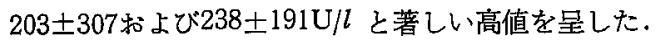

治潦後の活性值は非常習领酒者に和ける高度群39土 35 , 軽度群 $37 \pm 18$ ，むた常習领酒者に拈いては高度群63 \pm 67 ，軽度群81士69 と治療開始前に比し著しい改善がみ とめられた。

これらの所見から，対象症例の多くのむのにみとめら れた肝障害が，治療後に改善したことが窥われる。 た，常習飲酒者に拈ける $\boldsymbol{\gamma}$-GTP の推移から肝に対する アルンールの影響が推察される。

\section{血中脂筫}

入院時, 中性脂肪量叔よび $\beta$ リ术蛋白量の增加がみら れたものが多いが，組織学的にみとめられた肝脂肪化高 度群㧍よび軽度群それぞれの血中脂質の平均値には差は みとめられなかった.コレステロール量は注ぼ正常範囲

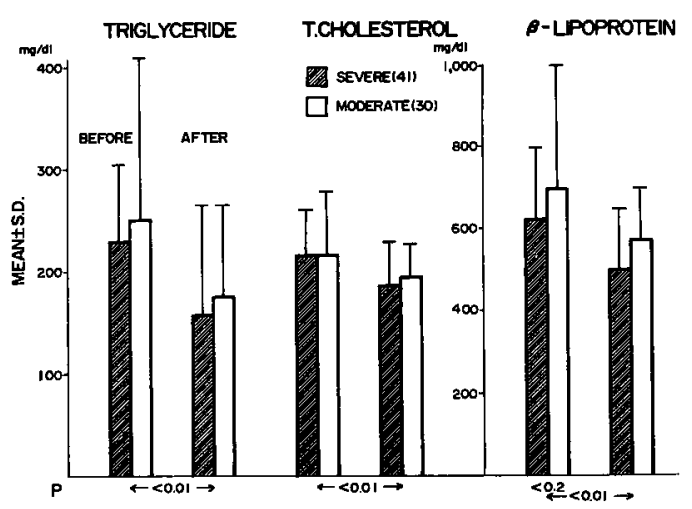

Fig. 3 Serum lipid levels in severe and moderate fatty liver before and after treatment.

内にとどまるものが多かった．治療により脂質各成分と むに改善され，したがって治療前後の平均値の間には有 意の差がみとめられた (Fig. 3).

早朝空腹時 FFA 拉よび血糖についても同様の傾向が みられた (Fig. 4)。な招糖尿病性変化をるつ症例に打 ける血糖值は，治療前 $165 \pm 56 \mathrm{mg} / \mathrm{d} l$ （平均値士標準偏 差)，治療後108土41 と低下したが $(\mathrm{p}<0.02)$ ，糖尿病性 変化をるたない症例においてはそれぞれ $97 \pm 9,90 \pm 11$ $\mathrm{mg} / \mathrm{d} l$ と軽度ながら有意な低下がみられた $(\mathrm{p}<0.02)$.

\section{ChE に対する血清脂質の影留}

16例飞おいて脂肪負荷試験を行ない，之の時の $\mathrm{ChE}$ 活性值および血中脂質量の変動を Fig. 5 と示した。脂 質は $2 \sim 6$ 時間後に著しく增量したが，ChE 活性値の

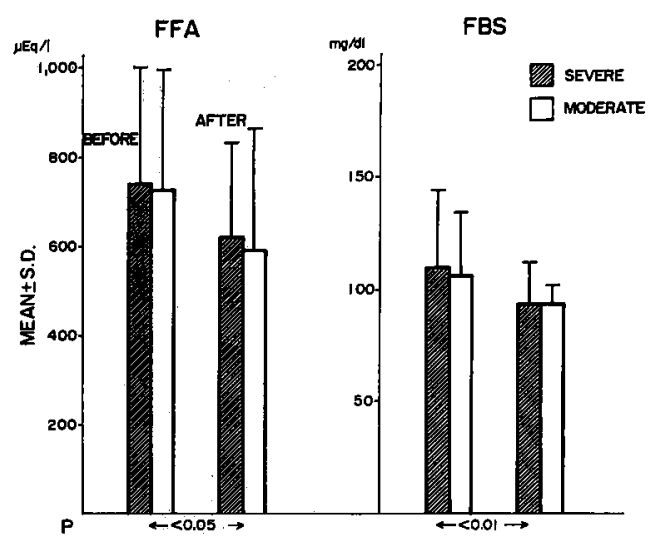

Fig. 4 Serum levels of fasting free fatty acids and blood sugar in severe and moderate fatty liver before and after treatment.
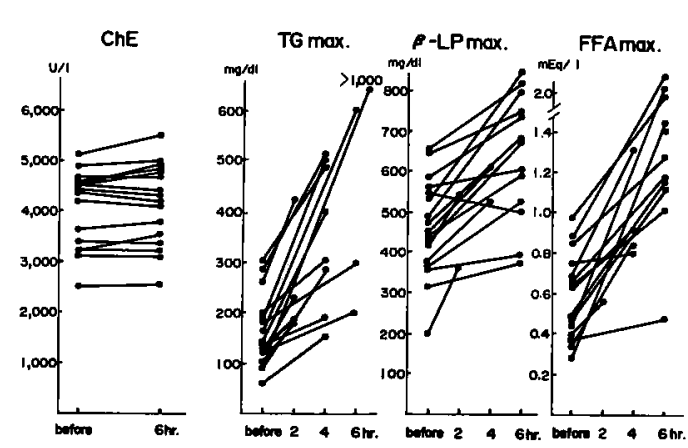

Fig. 5 Effect of hyperlipidemia on the activity of serum cholinesterase.

* max. indicates the maximum levels of lipids observed after test meal administration to patients.

変動は活とんどみられなかった。なお，これらの症例の うち5例において24時間後の活性值をむ測定したが，同 様に ChE 活性值の变化はみとめられなかった。これら のことは脂肪肝に拉いて入院時にみとめられた ChE 活 性値の上昇が高脂血症による直接の影響ではないことを 示唆する.

\section{血清アルブミンおよび ${ }^{131}$ I-RISA 半隇期}

治療前にアルプミン量 $4.5 \mathrm{~g} / \mathrm{d} l$ 以上, 最高 $5.1 \mathrm{~g} / \mathrm{d} l$ の 増量をみたものが，肝の脂肪化高度群および軽度群とも に40\%を占めたが，治療後には両群とも20\%を占めるに すぎなかった．個々の症例须いてみても，多かれ少か れ，治療後に軽隇していた．総じて治療前後の平均值に は有意差がみとめられた (Fig. 6).ただ，肝の脂肪化 


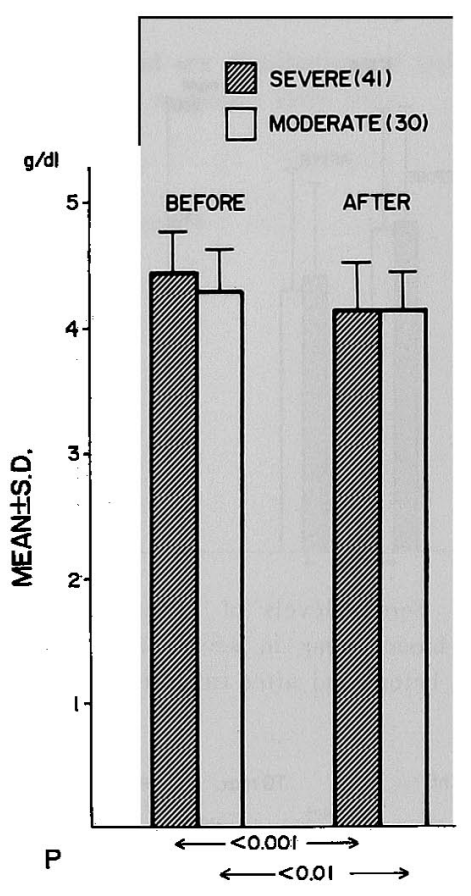

Fig. 6 Serum albumin in severe and moderate fatty liver before and after treatment.

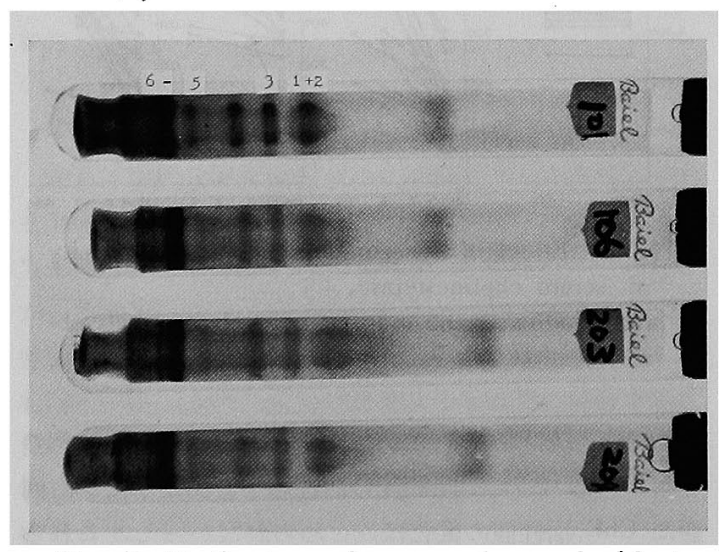

Fig. 7 Cholinesterase isozymes of normal subjects and fatty liver separated by polyacrylamide geI electrophoresis.

* Upper two colums $(101,106)$; normal, Lower two colums $(203,204)$; fatty liver

高度群と軽度群との平均値には差はみられなかった。な お，高度群13例において测定した血中 ${ }^{131}$ I-RISA 半減期 は7.0〜10.2日，平均8.2士1.5日であった。

\section{ChE isozymes}

脂肪肝の isozymes の各バンドの泳動像は健常者と同 一の像を示した（Fig. 7). 脂肪肝16例に拊ける各 isoz-

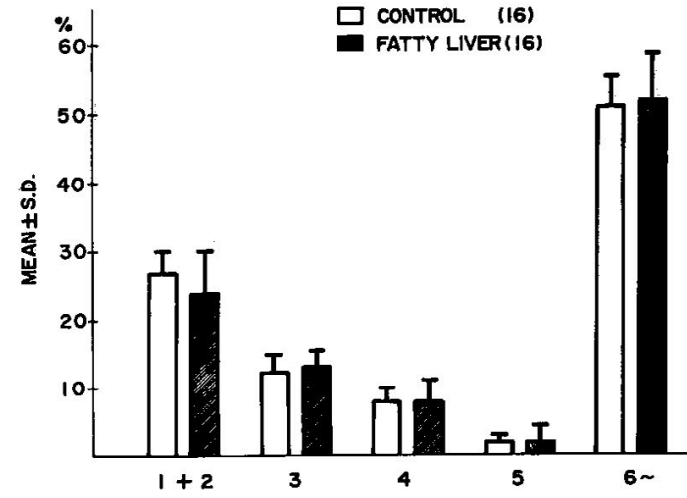

Fig. 8 Relative activities of serum cholinesterase isozymes in normal subjects and fatty liver.

yme のバンドの活性比をデンシトグラムにより測定し， 健常者のそれと比較したが，活性分布にも異常はみとめ られなかった (Fig. 8).

\section{考 案}

1940年代から血清 ChE 活性值の変動が肝疾患の病熊 観察ならびに診断の指標として重用されてきているが， 主に急性肝资や非代償性肝硬変に括ける活性値の低下に 関心が向けられてきだで).

他方， ChEの上昇を来す病態として糖尿病 ${ }^{14)}$ や肥満 ${ }^{15}$ が举げられているが，最近は特に高脂血症との関連が注 目されている ${ }^{15 \sim 20)}$. 就中, 脂肪肝に特ける ChE 活性値 の上昇 ${ }^{\mathrm{B}, 9)}$ ととすに，肝における脂質代謝異常が本酵素 活性值の上昇に関与していることを示唆している. しか し今日までその関連性は明確にされているわけではな く, 脂肪肝における肝の脂肪化の程度と $\mathrm{ChE}$ 活性值上 萛度との関連も明らかにされていない。

筆者らが今回対象 とした脂肪肝の症例の病因を過栄

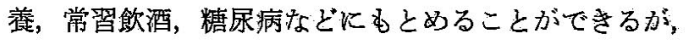
その他に病因不詳といわざるを得ないものもある。た た，今回の研究から，病因の如何を問わず，肝の脂肪化 につれて ChE 活性值が上昇することと，さらに肝脂肪 化の高度群と㪕度群との間には血中脂質量の差放とめ られないにもかかわらず, 高度群において ChE 活性值 が高いことなどの所見安得た、すなわち， ChE 活性值 は肝に和ける脂質代謝異常の程度を他のいずれの血液生 化学的検査による指標よりもよりよく反映することを示 している。また ChE 活性値の上昇は血中脂質の上昇と 平行してみられることが多いが，脂肪食負荷試験の成績 
にるみられるように， ChE 活性値の上昇は血中脂質の 直接影響をうけるるのではなく，肝における慢性的脂質 代謝異常㘧よび脂肪滴貯留それ自体による直接影響の関 与が示唆される. 脂質代謝異常に伴ら $\mathrm{ChE}$ の上昇機序 として, 次の 3 つの要因が考えられよう。

1. ChE の不活化の低下または turnover の延長

2. 肝細胞障害による醭素逸脱の增加

3. 肝に打ける産生, 分泌の充進

1. とついて考察してみよう. 脂肪肝では血中アルブ ミンが増加しているにもかかわらず，異化速度(半隇期) は平均8.2日であり，従来知られている正常人および肝 矣患患者に捺ける成績 ${ }^{11,21,22)}$ よりむやや短縮しており， 少なくとも蛋白異化の低下を示唆する半隇期の延長はみ とめられなかった。 また，シアル酸結合蛋白である ChE は，肝硬変や肝癌飞和ける結合比が変化し，そのアイソ ザイムに異常が生ずることが明らかにされている24)。こ の上らな䤃素蛋白の性状の変化比よる $\mathrm{ChE}$ 半減期の延

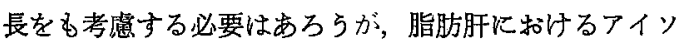
ザイム・パターンは健常者にみられるすのと全く同じで あったことから，その可能性も考文難い。

2. Kついて考察をすすめよう.急性肝炎など急激な 肝細胞の崩壊時に，他の肝細胞由来の酵素は逸脱し，血 中に上昇するにもかかわらず，ChE は逆に活性值が低 下するのであるから，2.の可能性もまた否定せざるを得 ない.

3.についての考察を述べる. ChE 活性值は肝手術 または肝移植後の抙機能低下時に低下し，機能が回復す るにつれて上昇するのであるが，その動きはアルプミン の変動に先行するのであるから，肝飞和ける蛋白合成能 を判定する最適の指標となる 群に㧍ける ChE 活性值の上昇は, 低アルブミン血症に 対応する肝の代償性フルブミン合成元進に伴う ChE 産 生立進によるものであり，したがってアルブミン輸夜に より合成を抑制すると $\mathrm{ChE}$ 活性值 る低下する ${ }^{26)}$ ，さら 飞最近 $\mathrm{ChE}$ が血中リポ蛋白代謝，䔟送に関与寸るとい 弓考芝 ${ }^{16,18)}$ から，興味ある知見の報告がつついている。 高脂血症症例におりる $\mathrm{ChE}$ 活性值上昇が，同じく肝ミ クロゾーム由来の $\gamma$-glutamyltransferase ${ }^{17)}$ や lecithincholesterol acyltransferase (LCAT) ${ }^{19)}$ の活性值上昇と平 行してみられまた動物実験的にはフェノバルビタール 投与に上る肝ミクロゾームの誘導が肝内 $\mathrm{ChE}$ の上昇を

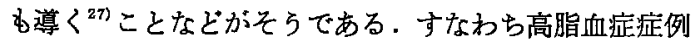
では，肝ミクロゾームに和忛るリポ蛋白（アポ蛋白）代
謝がえ進し，そのことによって肝に扣ける蛋白代謝異常 （合成六進）が括こり，ChE をはじめとするミクロゾー 么由来の酵素活性の上昇を来すと推定されている。しか しこれらの研究では高脂血症が対象症例とされており， 肝脂肪化の程度火関しては言及されていない，今回の筆 者らの研究に扔いてわ，ChE 活性值の上昇がアルブミ ソ，血中脂質，ことに $\beta$ リホ蛋白の增加と関連してみと められ，さらにまた非常習领酒例においても $\gamma$-GTP の

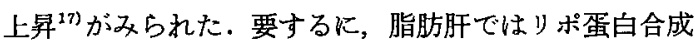
をはじめ非特異的蛋白代謝異常すなわち合成六進が特こ っていることが推察される。さらに脂肪化高度群におい て ChE 活性执よびアルブミン量の上昇がみられるので あるから，脂肋代謝異常が高度になるほど，蛋白代謝に も強い影響が及んでいると考元られる。まだ糖尿病性変 化をむつ症例群のみならず非糖尿病症例群においても， 血糖，FFA の上昇がみられ， ChE，血中脂質の改善とと むに，それらの改善低下るみられたことは，糖代謝系に 対する影響をる示唆するるのであるう．同時に GOT, GPT 活性值の異常が高頻度にみられたことは，これら の代謝異常に関連して，肝細胞の障害が発生しているこ とを示唆する所見と考えたい。

肝生検により，同じうに脂肪肝の組織像を得ても， 血液生化学的検查成績の対応は多彩である.最も頻度多 くみられるのは ChE 活性の上昇および $\beta$-globulin, $\beta$ lipoprotein の增量であるう，GOT<GPT の軽度ないし 中等度上昇がこれに次ぐ． BSP の軽度排泄遅延す みら れる。また $\gamma$-GTP 活性の上昇は常習飲酒者のみなら ず，非领酒者にもみとめられる。したがって，血液生化 学的にはこれらのものの組合せで脂肪肝を推定する。

脂肪肝浽慢性炎症性変化を伴うようになれば $\mathrm{ChE}$ の 変動と GOT, GPT, $\gamma$-GTP の変動とは捛抗するように なる。

脂肪化軽度群においても，高度群とよく似た $\mathrm{ChE}$ 活 性值の上算招よびその他の血液生化学的異常が䍩られ たことは，生検肝組織中の脂肪滴の多塞にかかわらず， 高度群と同様の代謝異常ならびに肝細胞障害がおこりつ つあることを示して扣り，脂肪肝の猃断とその臨床的評 価の再考を促す成績と思われる。すなわち，従来脂肪肝 の診断は肝組織所見に重点が技かれてきたが，脂肪化軽 度群といえども，いわば高度化への準備状態ともいうべ き代謝異常が括きつつあると考学られる。したがって脂 肪肝の診断には必ずしる肝組織中脂肪滴の量によること なく，脂質を中心とした代謝面からの検討が重視される 
べきであろう，その意味では今後さらに訮に拈ける脂質 代謝に関する検查法の確立が望ま机るが， ChE 活性值 は肝の代謝異常の一面を反映して括り, 現在, 脂肪肝の 診断上最も重要な指標と考兄られる.

な和高度栄堆障害 ${ }^{28)}$ や四塩化炭素肝障害 ${ }^{29)}$ では、 りポ 蛋白合成障害にもとづく脂肪肝が生ずるが，その際 $\mathrm{ChE}$ は低下することが知られている．脂肪肝状態の長期持続 および他の肝障害因子の付加により，肝障害が一層高度 化した時期や，薬物の関与飞より，リポ蛋白合成障害が 生じたならば，高度の脂肪化にもかかからず，ChE は 低下することが考学的るが，これらの点に関しては今 後の臨床的検討に待ちたい。

\section{結 語}

1. 血清コリンェステラーゼ活性は脂肪肝において上 昇し，その上昇度は肝組織脂肪化の程度と関連する。

2. その活性上昇は血清アルブミン量の增加と平行 し, 肝に和けるリポ蛋白合成六進に伴ら産生九進による むのと考兄られる。

3. 脂肪肝の長期持続によるか，付加障害因子が加わ ることにより肝障害が強められると， $\mathrm{ChE}$ 活性值は低 下L，GOT, GPT, $\gamma$-GTP などの活性值は拮抗的に上 昇する。

4. 脂肪肝の診断は単に肝生検組織中の脂肪滴の多寡 によらず，肝における脂質代謝異常の有無を指標とすべ きであると考えられ、コリンエステラーゼはその猃断に 有用である。

\section{文献}

1) Kunkel, H.G. \& Ward, S.M.: Plasma cholinesterase activity in patients with liver disease and nephrotic syndrome. J. Exper. Med., 67: 325, 1947.

2) Vorhaus, L.J. et al.: Measurement of serum cholinesterase activity in the study of the liver and biliary system. Gastroent., 15: $304,1950$.

3) Wilson, A. et al.: Plasma cholinesterase activity in liver disease. Its value as a diagnostic test of liver function compared with flocculation tests and plasma protein determinations. J. Clin. Invest., 31: 815, 1952.

4) LaMotta, R.V. et al.: Studies of cholin- esterase activity in hepatitis and cirrhosis. Gastroent., 33: 50, 1957.

5) Kekwick, G.O.: Serum cholinesterase activity in health and liver disease. Biochem. J., 76: $420,1959$.

6) Hunt, A.H. \& Lehman, H.: Serum albumin, pseudocholinesterase and transaminase in the assessment of liver function before and after venous shunt operations. Gut, 1: 303, 1960.

7) Gurtner, T. et al.: Comparative studies on cholinesterase activity and liver cells. Acta Anaest. Scand., 7: 69, 1963.

8) 岩村健一郎：脂肪肝の病因々治療関する研究 一第一報. 糖尿病性変化伴う脂肪肝飞対する Coenzyme A および adenosine triphosphate 投 与の影響. 肝臓, $12: 659,1971$.

9）柴田久雄他：高コリンエステラーゼ血症を呈し た症例. その2）脂肪肝診断上の意義. 肝臓， $17: 755,1976$.

10) Ellman, G.L. et al.: A new and rapid colorimetric determination of acetylcholinesterase activity. Biochem. Pharmacol., 7: 88, 1961.

11) Sterling, K.: The turnover rate of serum albumin in man as measured by ${ }^{131}$ I-tagged albumin. J. Clin. Invest., 30: 1228, 1951.

12) Juul, P.: Human plasma cholinesterase isozymes. Clin. Chim. Acta, 19: 205, 1951.

13) Matsuzaki, S. et al.: Separation of serum cholinesterase isozymes by an improved polyacrylamide gel electrophoresis and its application for the study of liver diseases (Part I). Gastroent. Japonica, 15: 33, 1980.

14) Thompson, R.H. \& Trounce, J.R.: Serum cholinesterase levels in diabetes mellitus. Lancet, 656, 1956.

15) Cucuianu, M. et al.: Pseudocholinesterase in obese and hyperlipemic subjects. Clin. Chim. Acta, 22: 151, 1968.

16) Kutty, K.M. et al.: Interrelationship between serum betalipoprotein and chclinesterase. Can. J. Biochem., 51: 883, 1972.

17) Cucuianu, M. et al.: Increase of serum $\gamma$-glu- 
tamyltransferase in hyperlipidemia: Comparison with serum pseudocholinesterase. Clin. Chim. Acta, 71: 419, 1976.

18) Kutty, K.M. et al.: Serum cholinesterase: Function in lipoprotein meta bolism. Experimentia, 33 : 420, 1976.

19) Cucuianu, M. et al.: Similar behaviour of lecithincholesterol acyltransferase and psuedocholinesterase in liver disease and hyperlipidemia. Clin. Chim. Acta, 85: 73, 1978.

20) Chu, M.I. et al.: Cholinesterase in serum and low density lipoprotein of hyperlipidemic patients. Clin. Chim. Acta, 85: 55, 1978.

21）朝倉 均, 松崎松平：消化器疾患におけるアル ブミンの 動的代謝学的研究. 慶応医学, 47 : 143,1970 .

22）小林健一：肝疾患に拈ける蛋白代謝一とくに albumin 代謝一についての研究. 日消会誌, 66: $809,1969$.

23) Svensmerk, O.: Human serum cholinesterase as a sialoprotein. Acta Physiol. Scand., 52: $267,1961$.
24）松崎松平他：慢性肝疾患に和けるコリンエステ ラーゼ活性とそのアイソザイム異常. 日消会 誌, 76, 臨時増刊号 404, 1979.

25) Evans, D.B. \& Lehman, H.: Pseudocholinesterase activity in liver transplantation. Lancet, 1040, 1971.

26) Vorhaus, L.J. \& Kark, R.M.: Serum cholinesterase in health and disease. Am. J. Med., 14: $707,1953$.

27) Lundkvist, U. \& Perlman, P.: Immunochemical studies of submicrosomal membranes from liver of normal and phenobarbital treated rats. Science, 152: 780, 1966.

28) Barclay, G.P.T.: Pseudocholinesterase activity as a guide to prognosis in malnutrition. Am. J. Clin. Ped., 59: 712, 1973.

29) Braver, R.W. \& Roor, M.A.: Effect of carbon tetrachloride induced liver injury upon acetylcholine hydrolyzing activity of blocd plasma of rats. J. Pharmcol. Exper. Therap., 88: 109, 1946.

\title{
An elevation of serum cholinesterase activity in fatty liver
}

\author{
Kenichiro Iwamura, Shohei Matsuzaki and Masaru Itakura*
}

Higher cholinesterase activities than a normal level $(2,900-4,500 \mathrm{U} / \mathrm{l})$ were observed in 80 and $60 \%$ of 41 severe and 30 moderate cases of fatty liver which were classified by histological examination of the liver. The value was significantly higher in a severe group (a mean of 5,311 U/l) than a moderate group $(4,748 \mathrm{U} / \mathrm{l})(\mathrm{p}<0.01)$, but was not related to an association of diabetes mellitus, obesity and habitual alcohol intake. The elevation was associated with significant elevations of serum lipids, albumin and $\gamma$-GTP. T 1/2 of 131I-RISA in 13 severe cases was moderately shortened (7.0-10.2 days). An isozyme pattern of ChE was normal. Thus, an elevation of $\mathrm{ChE}$ in fatty liver most likely reflects an increased production of the enzyme in the liver as well as lipoproteins and albumin induced by abnormal lipid metabolism.

\footnotetext{
* Department of Medicine III, School of Medicine, Tokai University (Isehara, Kanagawa)
} 